RESEACH ARTICLE

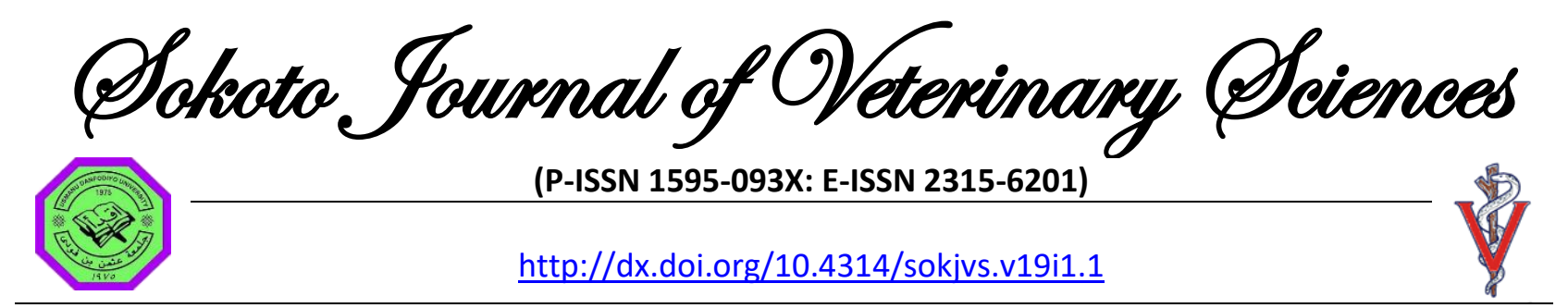

Adeniran et al. /Sokoto Journal of Veterinary Sciences, 19(1): 1 - 13.

\title{
Chemical profiling, in vitro antioxidant and antidiabetic assessment of flavonoids from the ethanol extract of Hermannia geniculata root
}

\author{
LA Adeniran ${ }^{1 *}$, CP Palanisamy ${ }^{2} \&$ AOT Ashafa ${ }^{2}$ \\ 1. Department of Physiology and Biochemistry, Faculty of Veterinary Medicine, University of Abuja, Nigeria \\ 2. Phytomedicine and Phytopharmacology Research Group, Department of Plant Sciences, University of the \\ Free State, Qwaqwa Campus, Phuthaditjhaba 9866, South Africa
}

\begin{abstract}
Copyright: (c) 2021 an open-access article published under the terms of the Creative Commons Attribution License which permits unrestricted use, distribution, and reproduction in any medium, provided the original author and source are credited.
\end{abstract}

*Correspondence: Tel.: +27788796568; E-mail: lateef.adeniran@uniabuja.edu.ng

\section{Abstract}

Publication History: Received: 14-05-2020 Revised: 04-09-2020 Accepted: 07-09-2020
Determination of the in vitro antioxidant and the inhibitory potential of flavonoids from Hermannia geniculata (FHG) roots on diabetes-linked enzymes was carried out. The chemical profiling of FHG roots extract was investigated using High Pressure Thin Layer Chromatography (HPTLC) fingerprint analysis. The reactive oxygen scavenging potential of the extract was analyzed. Starch solution (1\%) was reacted with different concentrations of FHG extract to determine the $\alpha$-amylase inhibitory potential of the extract while $\alpha$ - glucosidase inhibition assay was carried out through incubation of different concentrations of the extract followed by addition of $p$-ntrophenyl- $\alpha-D-$ glucopyranoside solution. HPTLC results indicated the presence of flavonoids/ phenolcarboxylic acid, and Kaempferol (Rf 0.80) were detected in the extract with retention factor Rf. ranging from 0.08 to 0.95 . FHG extract showed commendable antioxidant properties with IC50 values $(3.07 \pm 0.12,2.13 \pm 0.67) \mu \mathrm{g} / \mathrm{mL}$ for 1 , 1-diphenyl-2picrylhydrazyl (DPPH) and 2, 2-azino-bis (3-ethylbenzothiazoline-6-sulphonic) acid (ABTS) radicals which were lower and significantly different $(p<0.05)$ compared to standard silymarin with IC50: $(3.55 \pm 0.10,2.77 \pm 0.75) \mu \mathrm{g} / \mathrm{mL}$ for DPPH and ABTS respectively. The results indicated mild inhibition of $\alpha$-amylase with IC50: $(5.55 \pm 0.37)$ $\mu \mathrm{g} / \mathrm{mL}$ which was higher and significantly different $(\mathrm{p}<0.05)$ from acarbose with IC50: (3.81 \pm 0.29$) \mu \mathrm{g} / \mathrm{mL}$. Moreover, the extract showed $73 \%$ inhibition of $\alpha$-glucosidase. Kinetic studies of FHG extract revealed competitive and mixed non-competitive inhibition of $\alpha$ - amylase and $\alpha$-glucosidase respectively. This study indicated FHG capabilities of scavenging reactive oxygen species and reducing hydrolysis of starch responsible for post-prandial hyperglyceamia seen in type 2 diabetes mellitus.

Keywords: Antidiabetic, Antioxidant, Flavonoids, Hermannia geniculate, HPTLC

\section{Introduction}

Diabetes mellitus (DM), a metabolic disease associated with increased hyperglycaemia and subsequent organopathy is one of the most common diseases affecting 463 million people worldwide 
(Saeedi et al., 2019), while the global prevalence of DM in dogs and cat ranges from $0-3-1.3 \%$. The commonly affected breed of dogs includes Samoyeds, Poodles, Schnauzers, and Bichon Fries (Fall et al., 2007). Moreover, feline breeds appearing to be at increased risk of DM are Burmese cat, Norwegian Forest cats, Russian Blues and Abyssinians (Lederer et al., 2009; Ohlund et al., 2015). Increased oxidative stress resulting from an imbalance in the reactive oxygen species (ROS) and the endogenous antioxidant system, had been implicated in the pathogenesis and progression of DM (Bacanli et al., 2019). Studies on ROS has shown that it is involved in inflammation leading to $\beta$-cells destruction and/or insulin resistance which is key to diabetic etiology and its associated complications (Tangvarasittichai, 2015). Therefore, use of agents that have antioxidant capabilities may be able to preserve $\beta$-cells function through suppression of $\beta$ cell apoptosis helping in managing DM (Egea et al., 2017; Ogundajo et al., 2018; Marañon et al., 2020).

Several drugs are in use for treatment of DM type 2 which include acarbose, voglibose, and insulin injection in human, while acarbose, Novolin N, insulin and Glipizide are commonly used in dogs and cats but these drugs are expensive with debilitating side effects associated with their continual use (Nelson, 2000; Mazzaferro et al., 2003). Therefore, an alternative or complementary approach using herbal remedies in managing DM is advocated (Sabiu et al., 2016). Results of several studies have shown that many plants used in the folkloric treatment of have antioxidant capabilities and can improve $\beta$-cells function (Bibi et al., 2020; Phukhatmuen et al., 2020).

Plants contain different secondary metabolites like flavonoids, phenols, alkaloids, glycoside and terpenes which may be responsible for their pharmacological activities. Flavonoids are biologically active, non-nutritious, non-toxic secondary metabolites of plants that are produced in the cells of the plant through the phenylpropanoid pathway (Shashank and Abhay, 2013). The process of flavonoid biosynthesis starts from the metabolism of phenylalanine into 4-coumaroyl- CoA, (a key intermediate metabolite) which then moves into the main flavonoid biosynthetic pathway (Thomas, 2010; Falcone-Ferreyra et al., 2012). Flavonoid biosynthesis occurs in the cell cytosol and the product is stored in the cell vacuole (Agati et al., 2012). Flavonoids found in flowering plants are chalcones, flavonols, isoflavones, flavonones, aurones, proanthocyanidins and anthocyanins (Mohotti et al., 2020).
In vivo and in vitro studies have demonstrated the pharmacological importance of flavonoids, they regulate carbohydrate digestion and possess antioxidant properties (Wang et al., 2018; Claude et al., 2020; Rengarajan et al., 2020). Several factors contribute to the antioxidant capabilities of flavonoids, they include flavonoids' low redox potentials in the range of (2.13-1.0V) capable of reducing highly oxidized free radicals like superoxide, hydroxyl, peroxyl, and alkoxyl radicals (Mishra et al., 2013; Shashank \& Abhay, 2013). Structural/activity relationship evaluation of flavonoids suggested that the $\mathrm{OH}$ at the carbon (C3, C5) plus the -oxo- group at carbon 4 found in flavonols like kaempferol and other flavonoids skeleton may be responsible for its ability to chelate metal ions. Metal ions bind at these specific positions giving flavonoids the iron stabilizing properties (Van-Acker et al., 1996). In addition to this, the unsaturation in the 2-3 bond of the C-ring and also the $\mathrm{OH}$ in the 31, 41 carbon of the B- ring may be attributed to the antioxidant activities of flavonoids (Rice-Evans et al., 1996).

Hermannia geniculata is among the medicinal plant species frequently used in South Africa for the management of different diseases (Balogun et al., 2016). It is of the genus of flowering plant from the family Malnaceae (Essop et al., 2008). The plant is seen in South Africa and its vast majority being found in eastern Cape, Free State, Gauteng, KwaZulu-Natal, Limpopo and Mpumalanga, it is also found in the Saudi Arabia, West Africa, and north America (Essop et al., 2008).

It has been used in the treatment of several diseases like colic, diabetes mellitus, and other oxidative stress-induced illnesses (Moffett, 1993). The dry root material is chopped, boiled in water and taken three times daily to ameliorate blood sugar disorders. It is also used in the management of diarrhea, heartburn, stomach disorder and flatulence called "leletha" in pregnant Sotho women (Moffett, 1993; Balogun et al., 2016).

Based on the above knowledge, the present investigation was undertaken to determine the chemical constituents of the extract using HPTLC fingerprinting analysis, evaluate the in vitro antioxidant potentials of the plant, and also evaluate FHG extract capability to inhibit $\alpha$-glucosidase, $\alpha$ amylase enzymes and determine the mechanism of action of this plant extract on these carbohydrates metabolizing enzymes. This is because there is still the ongoing search for suitable antidiabetic agents from the plant, due to the adverse effect of the existing synthetic antidiabetic drugs. 


\section{Materials and Methods}

Plant collection, preparation and extraction

Hermannia geniculata roots were purchased from a local market in Puthaditjhaba, Qwaqwa, northern Free State Province, South Africa. Confirmation of the species identity was carried out with the herbarium specimen with a voucher specimen file number (5056.000-10700) (Moffett, 1993) at the University of Free State, Qwaqwa Campus, South Africa. It was also compared with our earlier Voucher specimen (Ash/med/05/2013/QwHB) (Kazeem \& Ashafa, 2015) at the herbarium.

Extraction of flavonoids: The roots were separated, washed under running tap to remove all debris and chopped into small pieces and air-dried at room temperature to a constant weight. The dried root materials were pulverized into fine powder using waring laboratory blender (Labcon, Durban, South Africa) and kept at $4{ }^{\circ} \mathrm{C}$ before extraction.

The flavonoids extract from Hermannia geniculata roots were obtained through a method described by Liu et al. (2015). Briefly, the powdered roots (30 g) was extracted twice with $70 \%$ ethanol $(1: 10, w / v)$ for $1 \mathrm{~h}$ at $25^{\circ} \mathrm{C}$. The extraction solution was centrifuged at 3,000 rpm for $5 \mathrm{~min}$ and passed through $0.45 \mu \mathrm{m}$ Millex-HV syringe filter unit and the residue obtained after filtration was further extracted with $50 \%$ ethanol. The extract was filtered with Whatman No. 1 filter paper and freeze-dried. The freeze-dried extract was dissolved in distilled water $(300 \mathrm{~mL})$ and stored at $-4^{\circ} \mathrm{C}$ before carrying out High-Performance Thin layer Chromatography and other in vitro assays.

Determination of extraction yield: The extraction yield of flavonoids of Hermannia geniculata roots (FHG) was calculated using the following formula: Extraction yield \% $=\mathrm{P} 0 / \mathrm{P} 1 \times 100$.

P0: the weight of the powder before extraction: P1: the weight of the dry extract after extraction.

Chemicals and reagents: The chemicals were purchased from different suppliers: Porcine pancreatic $\alpha$-amylase, rat intestinal $\alpha$ - glucosidase, 1,1-diphenyl-2-picrylhydrazyl, silymarin, acarbose and para nitrophenyl-glucopyranoside from SigmaAldrich Co., St Loius, USA, while starch soluble (extra pure) was obtained from J.T Bakerlnc., Phillipsburg, USA. Other chemicals and reagents were of analytical grade and the water used was glass distilled.

HPTLC finger print analysis of FHG extract: The assay method was as described by Reich \& Schibli (2007).
Briefly, $50 \mathrm{mg}$ of FHG extract was weighed accurately with an electronic weighing balance (Afcoset), dissolved in $250 \mu \mathrm{L}$ of ethanol, and centrifuged at $3000 \mathrm{rpm}$ for $5 \mathrm{~min}$. This solution was used as a test solution for HPTLC analysis. Then $2 \mu \mathrm{L}$ of the test solution and $2 \mu \mathrm{L}$ of standard solution were loaded as $5 \mathrm{~mm}$ band length in the $3 \times 10$ Silica gel 60 F254 TLC plate using Hamilton syringe and CAMAG LINOMAT 5 instrument.

The sample loaded plate was kept in Thin Layer Plate (TLC) twin trough developing chamber (after it has been saturated with solvent vapor) with respective mobile phase (Flavonoid) and the plate was developed in the respective mobile phase up to 90 $\mathrm{mm}$.

The developed plate was dried by hot air to evaporate solvents from the plate. The plate was kept in Photo-documentation chamber (CAMAG REPROSTAR 3) to capture the images at visible light, ultraviolet (UV) $254 \mathrm{~nm}$, and UV $366 \mathrm{~nm}$. The developed plate was sprayed with respective spray reagent (Flavonoid) and dried at $100^{\circ} \mathrm{C}$ in a hot air oven. The plate was photo-documented in visible light and UV $366 \mathrm{~nm}$ mode using Photodocumentation (CAMAG REPROSTAR 3) chamber. Before derivatization, the plate was fixed in the scanner stage (CAMAG TLC SCANNER 3) and scanning was done at UV $254 \mathrm{~nm}$. The Peak table, Peak display, and Peak densitogram were noted. The software used was a winCATS 1.3.4 version. Toluene-Acetone-Formic acid (4.5: 4.5: 1) was used as the mobile phase while $1 \%$ ethanolic aluminum chloride was used as the spraying reagent.

In vitro antioxidant assays: All experiments were conducted in triplicates and all the negative controls (blank) were prepared using the same procedure replacing the extract with distilled water. The percentage inhibition activity of all antioxidant assays was obtained using [(A0-A1)/A0] $\times 100$, where $A 0$ is the absorbance of the control and $A 1$ is the absorbance of the extract/standard. The $50 \%$ Inhibition Concentration (IC50) value was calculated and obtained from the linear regression equation using $y=m x+c$, where $y$ is the percentage activity and equals $50, m$ is the slope, $c$ is the intercept and $x$ is the IC50 value.

2, 2-Azino-bis (3-ethylbenzothiazoline-6-sulphonic) acid (ABTS) radical scavenger determination: The ability of the FHG extract to scavenge ABTS cation chromophore obtained from the oxidation of ABTS solution and potassium persulphate was determined according to a described method (Re et al., 1999). 
Metal chelating assay: The chelating of ferrous ions by FHG extract was estimated as described by Dinis et al. (1994).

Superoxide anion scavenging assay: Determination of superoxide anion radical scavenging potential of FHG extract was achieved according to Liu et al. (1997).

Hydroxyl radical scavenging ability: The ability of the plant extracts to prevent $\mathrm{Fe} 2+/ \mathrm{H} 2 \mathrm{O} 2$ induced decomposition of deoxyribose was carried out using the modified method Mathew \& Abraham (2006). Briefly, $100 \mu \mathrm{L}$ of extract (0.02. 0.04, 0.06, 0.08 and $1.00 \mu \mathrm{g} / \mathrm{mL}$ ), $120 \mu \mathrm{L}$ of deoxyribose ( $20 \mathrm{mmol} / \mathrm{L}$ ), 400 $\mu \mathrm{L}$ of phosphate buffer $(0.1 \mathrm{~mol} / \mathrm{L}), 40 \mu \mathrm{L}$ hydrogen peroxide $(20 \mathrm{mmol} / \mathrm{L})$ and $40 \mu \mathrm{L}$ iron two sulphate (500 $\mu \mathrm{mol} / \mathrm{L}$ ) were added into an Eppendorf tubes (2 $\mathrm{mL}$ ). Thereafter, there was an addition of $100 \mu \mathrm{L}$ distilled $\mathrm{H}_{2} \mathrm{O}$ and the mixture was incubated at $37^{\circ} \mathrm{C}$ for $30 \mathrm{~min}$. Termination of the reaction was carried out by the addition of $400 \mu \mathrm{L}$ thiobarbituric acid $(0.6 \%)$ and $0.5 \mathrm{~mL}$ trichloroacetic acid (2.8\%). About $300 \mu \mathrm{L}$ of this mixture were dispensed into a 96 -well microtiter plate and incubated with boiling water $\left(100^{\circ} \mathrm{C}\right)$ in a water bath for 20 min after which the absorbance was measured at 532 using a microplate reader (BIO-RAD, Model 680 Japan). The same procedure was carried using standards (silymarin) in place of the extract. The modification to this experiment was the concentration of the extract used ranging from $0.02-1.0 \mu \mathrm{g} / \mathrm{mL}$.

1, 1-diphenyl-2-picrylhydrazyl (DPPH) radical scavenging activity: The free radical scavenging activity of the FHG extract was evaluated based on its scavenging activities on the stable 1, 1-diphenyl2-picrylhydrazyl (DPPH) free radical. The method was as described by Braca et al. (2001).

In vitro antidiabetic assays: These were carried out by testing the inhibitory effect of FHG extract on $\alpha$ amylase and $\alpha$-glucosidase enzymes.

$\alpha$-amylase inhibitory assay: The $\alpha$-amylase inhibitory assay was carried out using the procedure of Apostolidis et al. (2007). Briefly, $250 \mathrm{~mL}$ of different concentrations of FHG extract/standard $(0.125,0.25$. 0.50. 0.75 , and 1.0$) \mu \mathrm{g} / \mathrm{mL}$ prepared in distilled water were placed into a test tube and freshly prepared $250 \mathrm{~mL}$ of $0.02 \mathrm{M} \mathrm{Na} 4 \mathrm{Po} 4$ buffer $(\mathrm{pH}$ 6.9) containing $\alpha$ - amylase solution were added. The resultant mixture was incubated for $10 \mathrm{~min}$ at $25^{\circ} \mathrm{C}$, this was followed by adding $250 \mathrm{~mL}$ of $(1 \%)$ starch solution prepared in $0.02 \mathrm{M} \mathrm{Na} 4 \mathrm{Po} 4$ buffer ( $\mathrm{pH}$ 6.9) at a timed interval. The whole mixture was incubated for $10 \mathrm{~min}$ at $25^{\circ} \mathrm{C}$.

Dinitrosalycylic acid (DNS) reagent $(500 \mathrm{~mL})$ was added and the whole mixture boiled in a water bath for $5 \mathrm{~min}$ to terminate the reaction. Absorbance was measured after diluting the mixture with $5 \mathrm{~mL}$ distilled water. Microplate reader (BIO-RAD, Model 680, Japan) was used to measure absorbance at 540 $\mathrm{nm}$. A similar method was used to prepare the control but distilled water replaced the extract. The procedure was carried out in triplicate.

$\alpha$-glucosidase inhibitory assay: The effect of the FHG extract on $\alpha$-glucosidase activity was determined according to the method described by Apostolidis et al. (2007). In brief, different concentrations (0.125 $1.0 \mu \mathrm{g} / \mathrm{mL}$ ) of extract/ standard were prepared in distilled water. Then, $50 \mathrm{~mL}$ of the extract solution were added into a test tube containing $100 \mathrm{~mL}$ of 0.1 $\mathrm{M}$ alpha glucosidase solution preincubated in $0.1 \mathrm{M}$ phosphate buffer $\mathrm{pH}$ (6.9). The resultant mixture was dispensed into a well-labeled 96 -well plate and incubated for $10 \mathrm{~min}$ at $25^{\circ} \mathrm{C}$. Further addition of 50 $\mathrm{mL}$ of $5 \mathrm{nmoL}$ of $\mathrm{p}$-nitrophenyl- $\alpha$-D-glucopyranoside (pNpG) solution prepared in $0.1 \mathrm{M} \mathrm{Na4Po4}$ buffer (pH 6.9) was made into each well at timed intervals and the reaction mixture incubated for $5 \mathrm{~min}$ at $25^{\circ} \mathrm{C}$. The absorbance of the mixture which determines the extract inhibitory effect was measured at $405 \mathrm{~nm}$ using a microplate reader (BIORAD, Model 680 Japan). The same methodology applies to the control, the extract was replaced by distilled water. The experiments were conducted in triplicate.

\section{Kinetic studies}

The mechanism of action of FHG inhibition of $\alpha$ amylase and $\alpha$-glucosidase was determined.

Mode of $\alpha$-amylase inhibition: Mode of $\alpha$-amylase inhibition assay was conducted using a described method by Nagata et al. (2015), in brief, $250 \mathrm{~mL}$ of (5 $\mathrm{mg} / \mathrm{mL}$ ) standard/extract of FHG were initially incubated with $250 \mathrm{~mL}$ of $0.5 \mathrm{mg} / \mathrm{mL}$ solution of $\alpha$ amylase at $25^{\circ} \mathrm{C}$ for $10 \mathrm{~min}$ in one set of test tubes, while in another test tube $\alpha$-amylase was preincubated with $250 \mathrm{~mL}$ of $0.1 \mathrm{M} \mathrm{Na} 4 \mathrm{Po} 4$ buffer $(\mathrm{pH}$ 6.9). Initiation of the reaction in the two sets of test tube occurred with the addition of $250 \mathrm{~mL}$ of (5\%) starch solution at an increasing concentration (0.3150.00) $\mu \mathrm{g} / \mathrm{mL}$. After incubating the mixture for 10 min at $25^{\circ} \mathrm{C}, 0.01 \mathrm{mM}$ of dinitrosalycylic acid (DNS) $(500 \mathrm{~mL})$ was added and the reaction was 
terminated after boiling for 5 min. Calculation of the amount of reducing sugar liberated was done spectrophotometrically using the maltose standard curve converted to reaction velocities. A double inhibition (Lineweaver \& Burk, 1934).

Mode of $\alpha$-glucosidase inhibition: The kinetics of inhibition of $\alpha$-glucosidase activities of FHG extract was carried out using a method described by Nagata et al. (2015). Briefly, pre-incubation of $50 \mu \mathrm{L}$ of 5 $\mathrm{mg} / \mathrm{mL}$ FHG extract with $100 \mu \mathrm{L}$ of $0.1 \mathrm{M}$ of $\alpha$ glucosidase solution at $25^{\circ} \mathrm{C}$ for $10 \mathrm{~min}$ was carried out in one set of the test tube, in another set of test tube pre-incubation of $\alpha$-glucosidase in $50 \mu \mathrm{L}$ of 0.1 $\mathrm{M} \mathrm{Na4Po} 4$ buffer ( $\mathrm{pH}$ 6.9) was carried out. $50 \mathrm{~mL}$ of different concentrations $0.31-50.00 \mu \mathrm{g} / \mathrm{mL}$ of 0.05 $\mathrm{M}$ pNpG were added to both sets of the reaction mixture to start the reactions. Then $500 \mathrm{~mL}$ of $0.1 \mathrm{M}$ sodium carbonate at $25^{\circ} \mathrm{C}$ for 10 mins were added to terminate the reaction. Calculating the released reducing sugar was done colourimentrically using a p-nitrophenol standard curve.

\section{Statistical data analysis}

Statistical analysis was performed using a Graph Pad Prism 5 statistical package (Graph Pad Software, San Diego, MA, USA). Data were expressed as means of replicate determinations \pm SD for in vitro assays, and was subjected to two-way analysis of variance followed by Bonferroni: comparisons of all pair of columns, Statistical significance was considered at $P$ $<0.05$.

\section{Results}

Flavonoids yield from the extraction of $30 \mathrm{~g}$ of plant materials was $1.68 \mathrm{~g}$. The HPTLC fingerprint analysis of the flavonoids was carried out to determine the flavonoids profile present in FHG extract. The result of the different $\mathrm{Rf}$ values and their various chromatograms are presented in Table 1 and Figures 1a-1c. The result shows the presence of flavonoid/ phenol carboxylic acid in the FHG extract. The peak seen at Rf 0.80 from the chromatograms confirmed reciprocal (Lineweaver-Burk) plot (1/v versus $1 /[\mathrm{S}]$ ) where $v$ is reaction velocity and [S] is the substrate concentration was plotted to determine the mode of

the presence of kaempferol in the FHG extract. This is achieved through its similarities with the $\mathrm{Rf}$ value of the standard (kaempferol Rf: 0.80). The chemical structure of the identified compound (kaempferol) in the extract is shown in Figure 2.

The results of the in vitro antioxidant potentials of the flavonoid of Hermannia geniculata (FHG) are presented in Table 2 and Figures 3a-e. The FHG did scavenge/ chelate and showed remarkable potentials when compared to the standard (silymarin). This is seen by comparing their IC50 values. The IC50 value of FHG extract on DPPH and ABTS radicals were (3.07 \pm 0.12 and $2.13 \pm 0.67)$ $\mu \mathrm{g} / \mathrm{mL}$ respectively which was lower and significantly different $(p<0.05)$ from silymarin with respective IC50: $3.55 \pm 0.10$ and $2.77 \pm 0.75 \mu \mathrm{g} / \mathrm{mL}$ for DPPH and ABTS. The percentage inhibition of FHG extract on $\mathrm{DPPH}$ and $\mathrm{ABTS}$ radicals was concentrationdependent (Figures $3 a$ and $\mathrm{c}$ ). The metal chelating activity of the FHG extract was also demonstrated against ferrous ion (Figure $3 \mathrm{~b}$ ). FHG showed great potential with IC50:4.14 $\pm 0.50 \mu \mathrm{g} / \mathrm{mL}$ which is lower and significantly different $(p<0.05)$ from silymarin with IC50: $5.30 \pm 0.98 \mu \mathrm{g} / \mathrm{mL}$.

Furthermore, the potential of FHG to scavenge free hydroxyl radical in vitro was also quantified. The result (Table 2, Figure 3e) shows that FHG extract has a similar capability with silymarin in scavenging the hydroxyl radicals with the best activity seen at a concentration of $0.1 \mathrm{mg} / \mathrm{mL}$. The respective IC50 values for FHG extracts and silymarin are 2.51 0.01 $\mu \mathrm{g} / \mathrm{mL}$ and 2.47士 $0.01 \mu \mathrm{g} / \mathrm{mL}$ respectively. Moreover, FHG extracts showed the greater capability of scavenging superoxide anion radicals in a concentration dependent manner (Figure 3d) with an IC50 value of $3.21 \pm 0.07 \mu \mathrm{g} / \mathrm{mL}$ value which is lower and significantly different $(p<0.05)$ from silymarin with IC50 value of $3.87 \pm 0.14 \mu \mathrm{g} / \mathrm{mL}$ (Table 2).

Table 1: The retention factor $\left(R_{f}\right)$ values of different peaks of flavonoid of Hermannia geniculata roots and the standard kaempferol

\begin{tabular}{cccccc}
\hline Track & Peak & Rf & Height & Area & Assigned substance \\
\hline Sample A & 1 & 0.08 & 11.4 & 188.9 & Unknown \\
Sample A & 2 & 0.15 & 25.1 & 588.3 & Unknown \\
Sample A & 3 & 0.22 & 43.9 & 1038.1 & Unknown \\
Sample A & 4 & 0.34 & 32.9 & 1043.3 & Flavonoid/Phenol carboxylic acid \\
Sample A & 5 & 0.80 & 119.8 & 4231.9 & Kaempferol \\
Sample A & 6 & 0.95 & 135.4 & 4767.4 & Unknown \\
STD & 1 & 0.80 & 371.8 & 6972.0 & Kaempferol standard \\
\hline
\end{tabular}




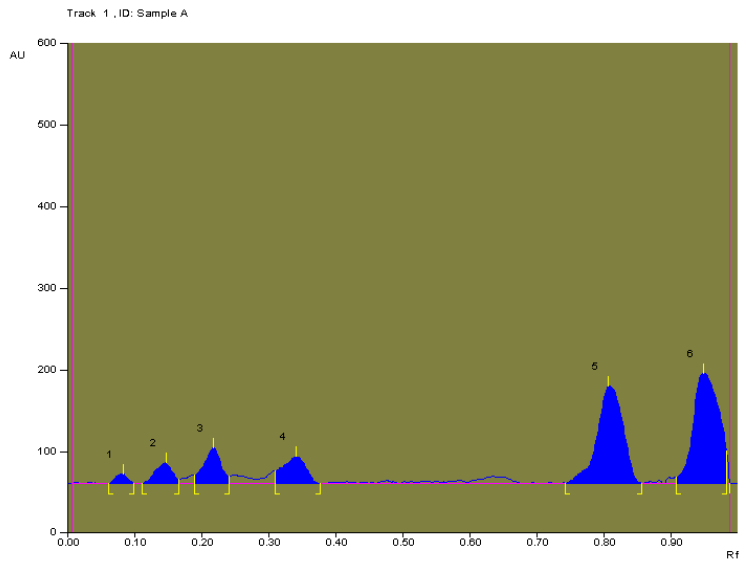

Figure 1a. FHG extract Peak densitogram display (scanned at $254 \mathrm{~nm}$ ). The $\mathrm{x}$ - axis is the Rf (retention factor) and the $y$-axis is $A U$ (area under curve)

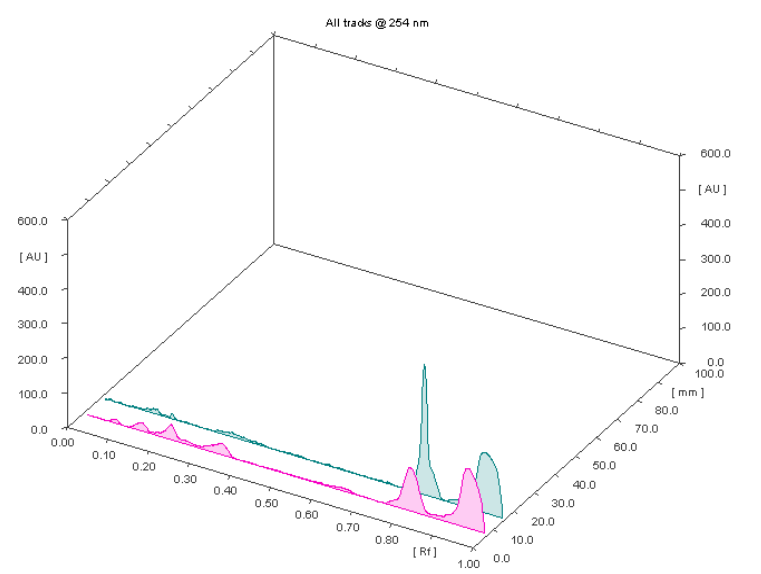

Figure 1c. The 3D display of all Tracts scanned at $254 \mathrm{~nm}$. The $x$ - axis is the $\mathrm{Rf}$ (retention factor) and the $\mathrm{y}$ axis is AU (area under curve)

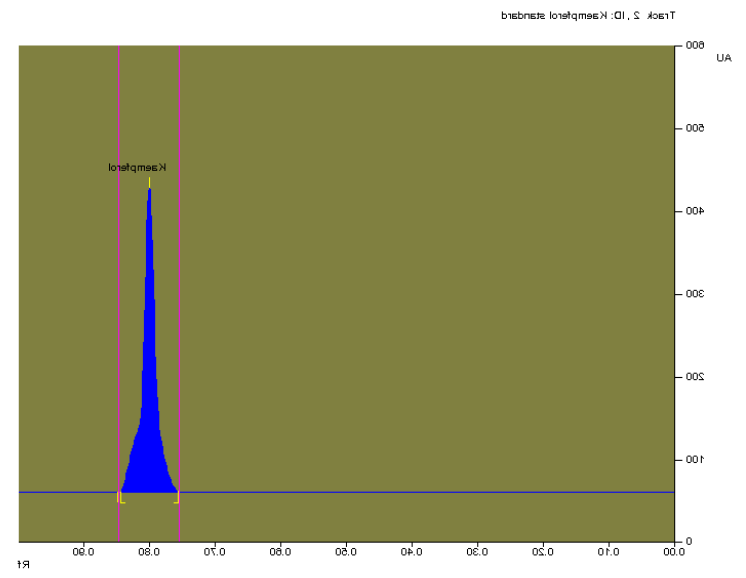

Figure 1b. Flavonoid standard peak densitogram display (scanned at $254 \mathrm{~nm}$ ). The $\mathrm{x}$ - axis is the $\mathrm{Rf}$ (retention factor) and the $y$-axis is $A U$ (area under curve)<smiles>O=c1c(O)c(-c2ccc(O)cc2)oc2cc(O)cc(O)c12</smiles>

Figure 2. The chemical structure of kaempferol identified in FHG extract

Table 2. The IC $\mathrm{C}_{50}$ of various antioxidant, $\alpha$ - amylase and $\alpha$ - glucosidase activities of total flavonoid of Hermannia geniculata roots extract

\begin{tabular}{|c|c|c|c|}
\hline Antioxidants & $I_{50}(\mu \mathrm{g} / \mathrm{mL})$ & Flavonols & Silymarin \\
\hline DPPH & & $3.07 \pm 0.12^{\mathrm{a}}$ & $3.55 \pm 0.10^{b}$ \\
\hline Metal chelating & & $4.14 \pm 0.50^{\mathrm{a}}$ & $5.30 \pm 0.98^{b}$ \\
\hline ABTS & & $2.13 \pm 0.67^{a}$ & $2.13 \pm 0.67^{a}$ \\
\hline Reducing power & & $2.72 \pm 0.13^{a}$ & $2.62 \pm 0.99^{a}$ \\
\hline Hydroxyl radical & & $2.51 \pm 0.01^{\mathrm{a}}$ & $2.47 \pm 0.01^{\mathrm{a}}$ \\
\hline Superoxide anion & & $3.21 \pm 0.07^{\mathrm{a}}$ & $3.87 \pm 0.14^{b}$ \\
\hline Antidiabetic & $1 \mathrm{C}_{50}(\mu \mathrm{g} / \mathrm{mL})$ & Flavonols & Silymarin \\
\hline$\alpha$ - amylase & & $5.55 \pm 0.37^{a}$ & $3.81 \pm 0.29^{b}$ \\
\hline$\alpha$-glucosidase & & $1.37 \pm 0.19^{a}$ & $2.91 \pm 0.42^{b}$ \\
\hline
\end{tabular}

Values are means of triplicate determination $(n=3) \pm$ standard deviation. ${ }^{\text {ab }}$ Values with different alphabets across the rows are significantly different $(p<0.05)$. Silymarin was used as the standard for antioxidant assays while acarbose used the standard for antidiabetic assay

Also, the in vitro enzymatic inhibitory potential of FHG extract on general and specific carbohydrate metabolic enzymes of $\alpha$-amylase and $\alpha$-glucosidase was assayed and results displayed in Table 2, Figures $4 \mathrm{a}$ and $4 \mathrm{~b}$. However, the potential of the extract to inhibit $\alpha$-amylase activities was lower at all 


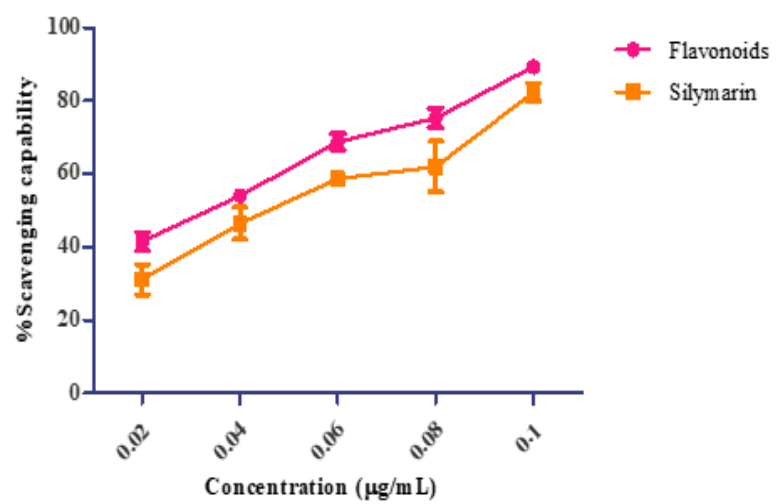

Figure 3a: DPPH radical scavenging capability of Hermannia geniculata flavonoids extract. Values are mean \pm standard deviation (SD) of triplicate determinations

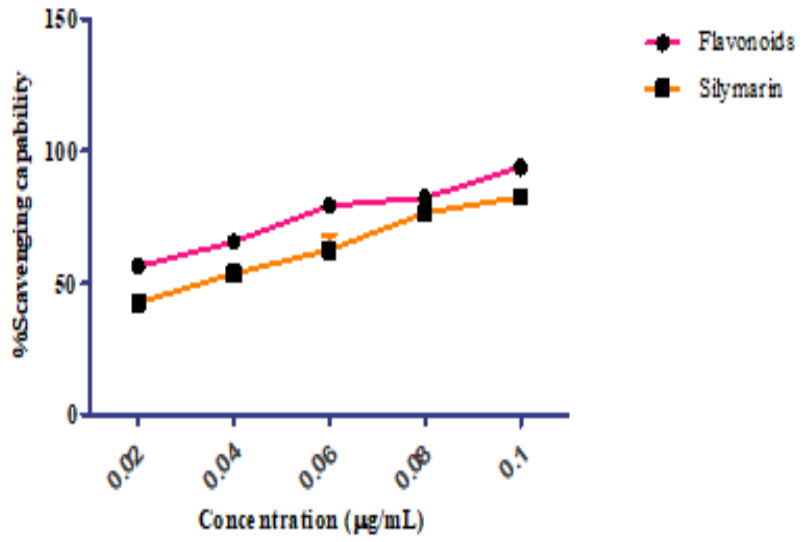

Figure 3c. ABTS radical scavenging activities of the flavonoids of Hermannia geniculata root extracts. Values are mean \pm standard deviation (SD) of triplicate determinations

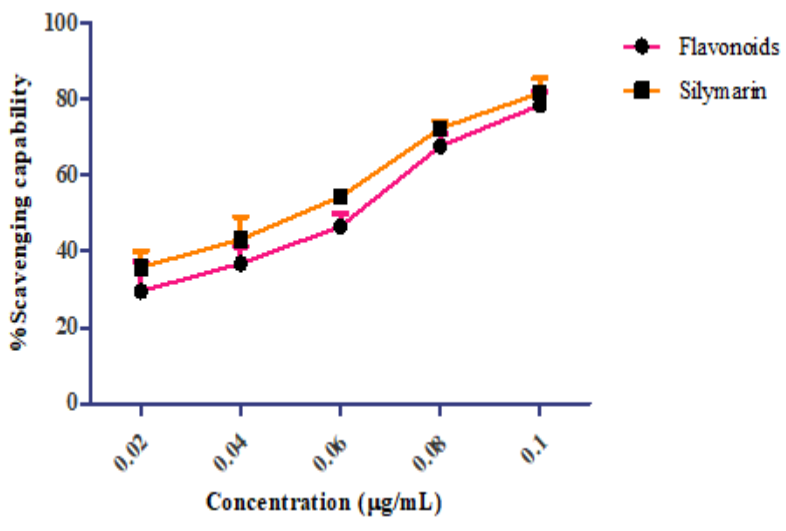

Figure 3e. The hydroxyl radical scavenging capabilities of the flavonoids of Hermannia geniculata root extracts. Values are mean \pm standard deviation (SD) of triplicate determinations

concentrations compared to the reference compound (acarbose), the IC50 value of FHG extract

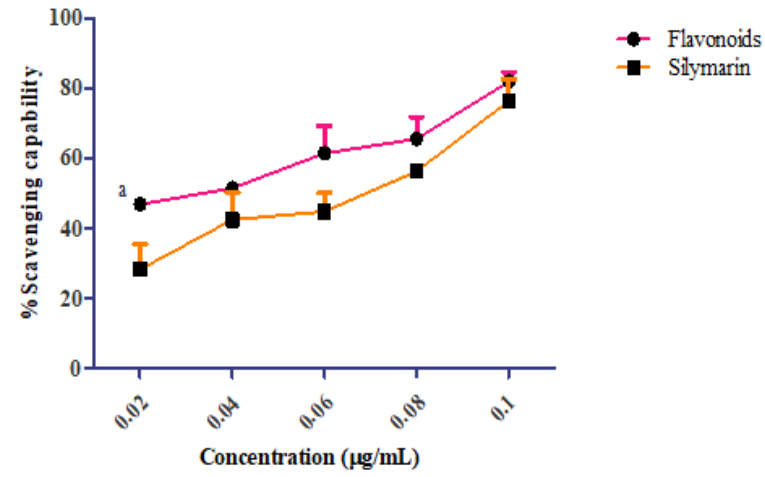

Figure 3b. Metal chelating activities of the flavonoids of Hermannia geniculata root extract. Values are mean \pm standard deviation (SD) of triplicate determinations

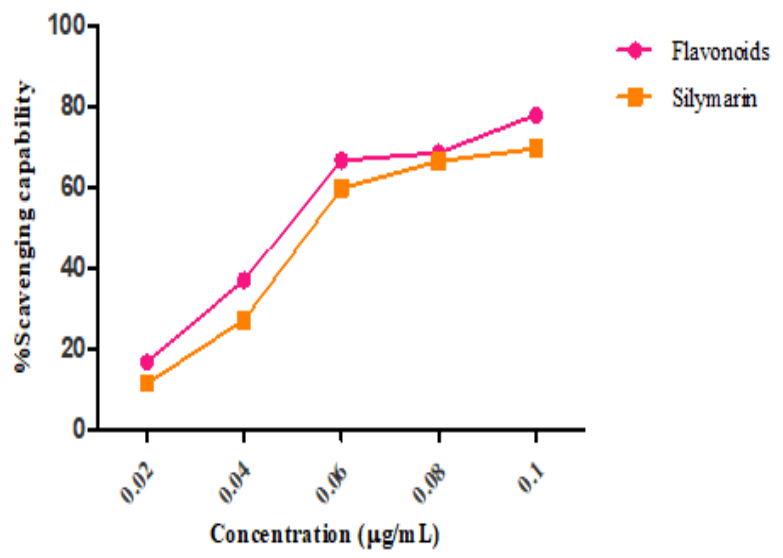

Figure 3d. Superoxide anion radical scavenging capabilities of the flavonoids of Hermannia geniculata root extracts. Values are mean \pm standard deviation (SD) of triplicate determinations

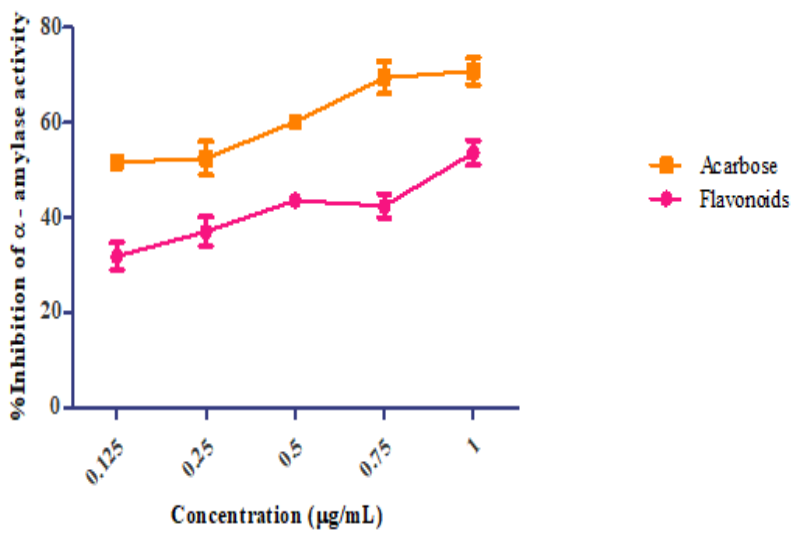

Figure 4a. Inhibitory potential of Hermannia geniculata root flavonoids extract on specific $\alpha$-amylase activity. Values are Mean \pm standard deviation (SD) of triplicate determinations

was $5.55 \pm 0.37 \mu \mathrm{g} / \mathrm{mL}$ which is higher and significantly different $(p<0.05)$ from acarbose with a 
lower IC50: $3.81 \pm 0.29 \mu \mathrm{g} / \mathrm{mL}$ but FHG extract exhibited higher inhibition of $\alpha$-glucosidase enzyme than acarbose with their respective IC50 values of $1.37 \pm 0.19 \mu \mathrm{g} / \mathrm{mL}$ and $2.91 \pm 0.42 \mu \mathrm{g} / \mathrm{mL}$.

The kinetic study for the probable mode of inhibition of the enzymes displayed in Figure 5 a showed that FHG extract exhibited independent inhibition of the $\alpha$ - amylase enzyme. The double reciprocal plot revealed a decrease in the $\mathrm{km}$ value of the extract compared to the control while their velocities remain constant thus suggesting a competitive mode of inhibition. The $V_{\max }$ is $2.5 \mu \mathrm{m} / \mathrm{min}$ and the $\mathrm{km}$ values reduce from $32 \mathrm{mg}$ to $14 \mathrm{mg}$ for the control and the extract respectively. The mode of inhibition of $\alpha$-glucosidase enzyme by FHG extract (Figure $5 b$ ) showed that the Vmax of the extract increased from $0.14 \mu \mathrm{m} / \mathrm{min}$ for the control to $2.70 \mu \mathrm{m} / \mathrm{min}$ for FHG extract while the $\mathrm{Km}$ value remained the same at a constant concentration signifying a non-competitive mode of inhibition.

\section{Discussion}

High performance thin layer chromatography (HPTLC) fingerprinting is an offline throughput planar chromatography technique used in identifying marker compounds present in medicinal plants (Reich \& Schibli, 2007). The presence of flavonoids in the extract were confirmed with $\mathrm{Rf}$ values (0.080.95). The specificity of the method was ascertained by analyzing the standard and the sample with similar chromatographic conditions. Chromatograms revealed similarities for both the standard and the test samples. Moreover, the detection of kaempferol in the FHG extract was confirmed with Rf 0.80 which is similar to the standard kaempferol with $\mathrm{Rf} 0.80$.

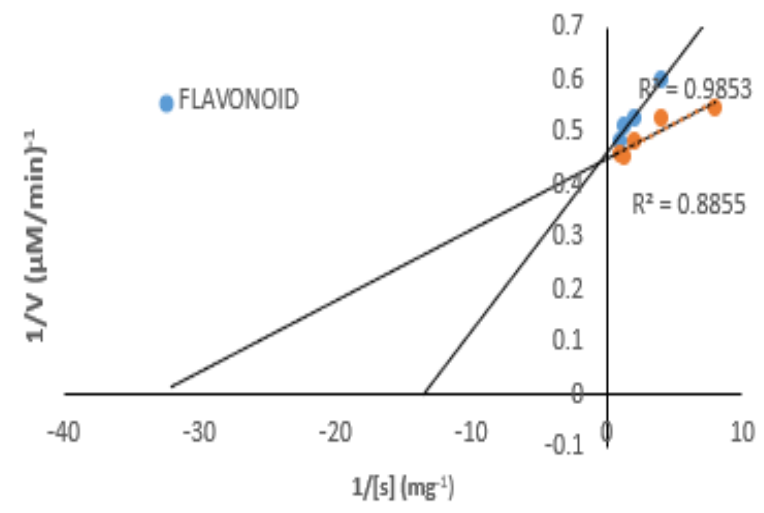

Figure 5a. Lineweaver-Burk plot of total flavanoid extract eliciting competitive inhibition on $\alpha$-amylase activity. Results represent mean \pm standard deviation (SD); $(n=3) ;(p<0.05)$
Also, similar densitogram and 3D display of the tracts confirmed the detection of kaempferol in the FHG extract. Kaempferol is a flavonol, a product of aromadendrin derived from the flavonoid biosynthetic pathway in a reaction catalyzed by flavonol synthase (Malla et al., 2012). Several glycosides of kaempferol derivatives have been identified in medicinal plants (Teffo et al., 2010). This will be the first time kaempferol was detected in Hermannia geniculata roots extract.

Flavonoids are polyphenolic compounds distributed naturally in plants. They are plant secondary metabolites with reactive oxygen species (ROS) quenching capacity in both plant and animal cells (Agati et al., 2012; Rengarajan et al., 2020). The unregulated production of ROS by different body cellular mechanisms lead to oxidative stress which is an underlying cause of $\beta$-cell destruction and insulin resistance seen in diabetes mellitus type 2 and its various complications (Deo et al., 2016). DPPH scavenging methods, ABTS decolorization assay, hydroxyl radical averting capacity, superoxide anion radical scavenging assay and metal chelating capabilities are models for evaluating the antioxidant potency of medicinal plants. (Alam et al., 2013; Egea et al., 2017). In this study, the results of antioxidant assays showed that FHG extract has a good antioxidant activity which is comparable to the standard silymarin. FHG exhibited a lower IC50 value for DPPH, ABTS, and superoxide anion radicals compared to the standard. The extract also showed iron-chelating capability which will tend to reduce the concentration of transition ion that catalyzes lipid peroxidation in biological systems (Jomova \& Valko, 2011). Appreciable hydroxyl radical

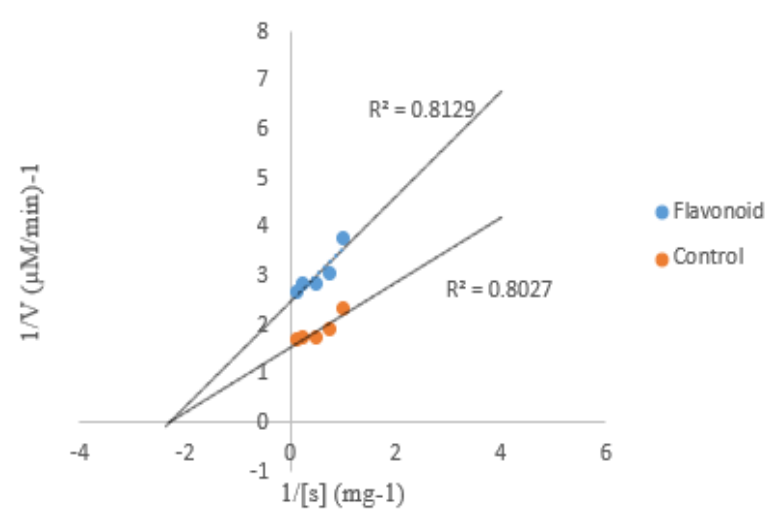

Figure 5b. Lineweaver-Burk plot of total flavonoids extract eliciting non-competitive inhibition on $\alpha$ glucosidase activity. Results represent mean \pm standard deviation (SD); $(n=3) ;(p<0.05)$ 
scavenging capability of FHG was also observed. Hydroxyl radical has been implicated in the production of harmful radicals that cause enormous damage to cellular components (Ogundajo et al., 2018). The standard curve of the percentage inhibition/scavenging/chelating effect and their respective IC50 values in this study showed a decrease in the concentration of the ROS which may be a result of the scavenging effect of the FHG extract. Since the effect of vascular complication induced by hyperglycemia may be due to the reactive oxygen species (ROS) and free radicals in the biological system (Li et al., 2017), the scavenging of ROS and free radicals may be useful in controlling the pathogenesis of diabetes mellitus type 2 in both humans and animals.

$\alpha$ - amylase is an enzyme found in saliva and pancreas, which is responsible for conversion of polysaccharide to disaccharide while the $\alpha$ glucosidase found in the small intestine catalyzes the conversion of polysaccharides to disaccharides and monosaccharides (Oku et al., 2011). The inhibition of these enzymes delays the breakdown of carbohydrates in the small intestine thus controlling the blood glucose level associated with postprandial hyperglycemia commonly seen in type 2 diabetes mellitus.

The result obtained from $\alpha$ - amylase inhibitory activities in this study showed that FHG extract IC50 value is $5.55 \mu \mathrm{g} / \mathrm{mL}$ which is higher and significantly different $(p<0.05)$ from acarbose IC50 value of 3.81 $\mu \mathrm{g} / \mathrm{mL}$. The possession of higher IC50 value of FHG than the standard drug in the inhibition of $\alpha$ amylase signifies mild inhibition of the enzyme which is a good quality of an antidiabetic agent (Sabiu et al., 2016). This result implies that FHG is a mild inhibitor of $\alpha$ - amylase compared to acarbose, excessive inhibition of $\alpha$ - amylase enzyme by acarbose has been associated with side effect like diarrhea, and stomach upset (Kazeem et al., 2013). This result is consistent with Kim et al. (2000) which observed a less potent than acarbose inhibitory effect of flavonoids.

The inhibitory effect of FHG extract on $\alpha$-glucosidase was also evaluated and, it showed an IC50 value of $1.37 \mu \mathrm{g} / \mathrm{mL}$ which is lower and significantly different $(p<0.05)$ compared to acarbose IC50 value of 2.91 $\mu \mathrm{g} / \mathrm{mL}$. The lower IC50 value of FHG than the standard drug used in this study indicated stronger inhibition of the $\alpha$-glucosidase enzyme. FHG extract potent inhibition of $\alpha$-glucosidase compared with the standard antidiabetic drug in this study showed a great potential of the FHG extract which may be further explored in the quest for potent antidiabetic drug.

Strong inhibition of $\alpha$-glucosidase will affect the level of carbohydrate catabolism and subsequent postprandial hyperglycaemia seen in type 2 diabetes mellitus. This finding is consistent with the work of Kim et al. (2000) who observed Leutonin-7- oglycoside isolated from flavonoids extract was a more potent inhibitor of $\alpha$-glucosidase enzyme than acarbose. Also, Tadera et al. (2006) observed that yeast $\alpha$-glucosidase was potently inhibited by flavonoids like anthocyanidin, isoflavone, flavanol, and flavonol groups than acarbose. The presence of a double bond in the C- ring, the catechol group in the B-ring seen in the flavonoids' the skeleton may be responsible for the potent inhibitory effect on $\alpha$ glucosidase enzyme (Tadera et al., 2006).

Due to the observed mild and strong inhibitory properties of FHG on $\alpha$-amylase and $\alpha$-glucosidase enzymes respectively, the extract was tested for the enzyme kinetics of inhibition with the aid of Lineweaver-Bulk plots. The enzyme kinetic study of $\alpha$ - amylase showed that FHG extract competitively inhibits $\alpha$ - amylase enzyme. The kinetics further revealed an increase in the $\mathrm{Km}$ value of the inhibitor while the Vmax remain constant. The lower $\mathrm{Km}$ value of the inhibitor means a higher affinity of the inhibitor compared to the substrate for the enzyme thus, competitively inhibiting $\alpha$ - amylase hydrolysis of disaccharide. This is only applicable if both concentrations of the inhibitor and the substrate are kept constant (Johnson \& Goody, 2011).

The mode of inhibition of $\alpha$-glucosidase is mixed non-competitive. The $\mathrm{Km}$ values remain constant while there is a change in the Vmax. This is consistent with Tadera et al. (2006) who described non-competitive inhibition of an $\alpha$-glucosidase enzyme by FHG.

From the kinetic studies, competitive and mixed non-competitive inhibition of $\alpha$ - amylase and $\alpha$ glucosidase enzymes will cause a delay in the absorption of glucose and fructose in the gastrointestinal tract and reduce the gastric emptying rate which alters insulin secretion (Celleno et al., 2007). The effect of reduced starch catabolism will promote weight loss through a reduction in the digestive bioavailability of carbohydrate derived calories (Olaokun et al., 2016).

In this study, the HPTLC fingerprinting analysis of FHG showed the presence of kaempferol and other flavonoids. The FHG extract showed its ROS and free radicals scavenging capabilities, it also demonstrates appreciable inhibition of $\alpha$ - amylase and $\alpha$ glucosidase enzymes. This suggested that FHG may 
be a potential agent that may be explored in order to mitigate oxidative stress and postprandial hyperglycemia seen in diabetes mellitus type 2 in humans and animals. There is a need for further in vivo antioxidant and antidiabetic studies of the plant in diabetic animals.

In conclusion, this study revealed the chemical profile of FHG extract, and also showed that the extract has antioxidants and antidiabetic potential in vitro. It may be deduced from the result that FHG extract has antioxidant and antidiabetic potential. Its probable mechanism of antidiabetic action is through the competitive inhibition of $\alpha$-amylase and non-competitive inhibition of $\alpha$-glucosidase enzymes.

Further work on isolation and characterization of the bioactive flavonoid in FHG extract and the in vivo antidiabetic studies in cat and dog should be conducted.

\section{Conflicts of Interest}

The authors declare no conflict of interest.

\section{References}

Agati G, Azzarello E, Pollastri S \& Tattini M (2012). Flavonoids as antioxidants in plants: Location and functional significance. Plant Science, doi.10.1016/i.plantsci.2012.07.014.

Alam MN, Bristi NJ \& Rafiquzzaman M (2013). Review on in vivo and in vitro methods evaluation of antioxidant activity. Saudi Pharmaceutical Journal, 21(2): 143-152.

Apostolidis E, Kwon YI \& Shetty K (2007). Inhibitory potential of herb, fruit, and fungal-enriched cheese against key enzymes linked to type 2 diabetes and hypertension. Innovative Food Science and Emerging Technologies, 8(1): 46-54.

Bacanli M, Dilsiz SA, Başaran N \& Başaran AA (2019). Effects of phytochemicals against diabetes. Advances in Food and Nutrition Research, https://doi.10.1016/bs.afnr.2019.02.006.

Balogun FO, Tshabalala NT \& Ashafa AOT (2016). Antidiabetic medicinal plants used by the Basotho tribe of eastern free state: A review. Journal of Diabetes Research, doi.10.1155/2016/4602820.

Braca A, De-Tommasi N, Di-Bari L, Pizza C, Politi M \& Morelli I (2001). Antioxidant principles from Bauhinia tarapotensis. Journal of Natural Products, 64(7): 892-895.

Bibi Z, Ayaz Z, Alwahibi MS, Khan S, Rizwana $H$, Soliman DW, Alawaad A \& Abbasi AM (2020). In-silico elucidation of Moringa oleifera phytochemicals against diabetes mellitus. Saudi Journal of Biological Sciences, doi.10.1016/j.sjbs.2020.04.002.

Celleno L, Tolaini MV, D'Amore A, Perricone NV \& Preuss HG (2007). A dietary supplement containing standardized Phaseolus vulgaris extract influences body composition of overweight men and women. International Journal of Medical Sciences, 4(1), 45-52.

Claude DB, Bidingha G, Désiré P, Dzeu D, Bekono Y, Fifen R Yannick T, Pascal EO, Steven CNW, LucieTT Théophile D Pierre $\mathrm{K}$ \& Kamtchouing P (2020). Antihypertensive and antidiabetic activities of Erythrina senegalensis DC (Fabaceae) stem bark aqueous extract on diabetic hypertensive rats. Journal of Ethnopharmacology, doi.10.1016/j.jep.2019.112200.

Deo P, Hewawasam E, Karakoulakis A, Claudie DJ, Nelson R, Simpson BS, Smith NM \& Semple SJ (2016). In vitro inhibitory activities of selected Australian medicinal plant extracts against protein glycation, angiotensin converting enzyme (ACE) and digestive enzymes linked to type II diabetes. $B M C$ Complementary and Alternative Medicine, 16(1): 1-11.

Dinis TCP, Madeira VMC \& Almeida LM (1994). Action of phenolic derivatives (acetaminophen, salicylate, and 5aminosalicylate) as inhibitors of membrane lipid peroxidation and as peroxyl radical scavengers. Archives of Biochemistry and Biophysics, 315(1): 161-169.

Egea J, Fabregat S, Frapart YM, Ghezzi P,Agnes G, Thomas K, David B, Esther B, Alberto B, Serge $P$, Bottari PM, Brito G, Carrara Al, Casas A, Chatzi N, Chondrogianni M, Conrad MS, Cooke JG,Costa A, Cuadrado PM, Chan D, Barbara D, Smet B, Debelec BHK, Dias JD, Dunn AJ, Edson ME, Assar J, El-Benna P, Ferdinandy AS, Fernandes KE, Fladmark $U$, Förstermann R, Giniatullin Z, Giricz A, Görbe $H$, Griffiths V, Hampl A, HanfJan H, Pablo $H$, Agustín $M$, Hillion J, Huang $S$, Pidder J, DürrVincent JA, Joles B, Kalyanaraman D, Kaminskyy M, Karbaschi M, Kleanthous LO, Klotz BK, Sami K, Rafal KID, Kračun KH, Krause VT, Krieg J, Laranjinha ALH, Li A, Martínez RR, Matsui GJ, McBean SP, Meredith J, Messens $V$, Miguel $Y$, Mikhedlrina M, Milković A, Miranda-Vizuete MMM, Monsalve Pal, Mouthuy J, Mulvey T, Münzel V, Muzykantovlsabel TN, Nguyen M, 
Oelze N G, Oliveira CM, Palmeira N, Papaevgeniou A, Pavićević B, Pedre F, Peyrot MPG, Pircalabioru AR, PittHenrik E, Poulsenlgnacio PM, Pia RN, RobledinosAntón L, Rodríguez-MañasAnabela P. Rolo F, Rousset T, Ruskovska N, Saraiva S, Sasson K, Schröder K, Semen T, Seredenina A, Shakirzyanova GL, Smith T, Soldati BC, Sousa CM, Spickett A, Stancic MJ, Stasia H, Steinbrenner V, Stepanić $S$, Steven K, Tokatlidis E, Tuncay B, Turan F, Ursini J, Vacek O, Vajnerova K, Valentová F, VanBreusegem L, Varisli EA, Veal A, Suha YO, Yelisyeyeva NŽM, Zatloukalová J, Zielonka RM, Touyz A, Papapetropoulos TGS, Lamas HW, Schmidt FD Andreas D, (2017). Redox Biology European contribution to the study of ROS: A summary of the findings and prospects for the future from the COST action BM1203 (EU-ROS). Redox Biology, doi.10.1016/i.redox.2017.05.007

Essop $A B$, Zyl RL, Van-Vuuren SF, Van-Mulholland D \& Viljoen AM (2008). The in vitro pharmacological activities of 12 South African Hermannia species. Journal of Ethnopharmacology,doi.10.1016/j.jep.2008. 06.026.

Falcone-Ferreyra ML, Rius SP \& Casati P (2012). Flavonoids: Biosynthesis, biological functions and biotechnological applications. Frontiers in Plant Science, doi.10.3389/fpls.2012.00222.

Fall T, Hamlin HH \& Hedhammar A (2007). Diabetes mellitus in a population of 180,000 insured dogs: Incidence, survival, and breed distribution. Journal of Internal Medicine, 21(6): 1209-1216.

Johnson KA \& Goody RS (2011). The Original Michaelis Constant: Translation of the 1913 Michaelis-Menten Paper. Biochemistry, 50(39): 8264-8269.

Jomova K \& Valko M (2011). Importance of Iron Chelation in free radical-induced oxidative stress and human disease. Current Pharmaceutical Design, 17(31): 3460-3473.

Kazeem M \& Ashafa AOT (2015). Safety evaluation of aqueous root extract of Hermannia geniculata EckL. \& Zeyh. (Streculiaceae) in Wistar rats. European Journal of Integrative Medicine, 7(5): 508-516.

Kazeem MI, Adamson JO \& Ogunwande IA (2013). Modes of Inhibition of $\alpha$ - Amylase and $\alpha$ Glucosidase by Aqueous Extract of Morinda lucida Benth Leaf. BioMed Research International, doi.10.1155/2013/52757.

Kim J, Kwon C \& Son KH (2000). Inhibition of alphaglucosidse and amylase by luteolin, a flavonoid. Bioscience, Biotechnology and Biochemistry, 64(11): 2458-2461.

Lederer R, Rand JS \& Johnson NN (2009). Frequency of feline diabetes mellitus and breed disposition in domestic cats of Australia. Australia Veterinary Journal, doi.10.1016/j.tvjl.2007.09.019.

Li C, Miao X, Li F, Wang S, Liu Q, Wang Y \& Sun J (2017). Oxidative stress-related mechanisms and antioxidant therapy in diabetic retinopathy, doi.10.1155/2017/9702820.

Lineweaver H \& Burk D (1934). The determination of enzyme dissociation constants. Journal of the American Chemical Society, 56(3): 658666.

Liu F, Ooi VEC \& Chang ST (1997). Free radical scavenging activities of mushroom polysaccharide extracts. Life Sciences, 60(10): 763-771.

Liu Y, Wang H \& Cai X (2015). Optimization of the extraction of total flavonoids from Scutellaria baicalensis Georgi using the response surface methodology. Journal of Food Science and Technology, 52(4): 23362343.

Malla S, Koffas MAG, Kazlauskas RJ \& Kim BG (2012). Production of 7-O-Methyl aromadendrin, a medicinally valuable flavonoid, in Escherichia coli. Applied and Environmental Microbiology, 78(3): 684-694.

Marañon AM, De-lannantuoni F, Abad-Jiménez Z, Canet $F$, Diaz-pozo $P$, Lopez-Domènech $S$, Ana J, Carlos M, Guillermo M, Nadezda A, Milargros R \& Victor VM (2020). Relationship between PMN-endothelium interactions, ROS production and BECLIN 1 in type 2 diabetes. Redox Biology, doi.10.1016/i.redox.2020.101563

Mathew S \& Abraham TE (2006). In vitro antioxidant activity and scavenging effects of Cinnamomum verum leaf extract assayed by different methodologies. Food and Chemical Toxicology, 44(2): 198-206.

Mazzaferro EM, Greco DS, Turner AS \& Fellma MJ (2003). Treatment of feline diabetes mellitus using alpha-glucosidase inhibitor and low carbohydrate diet. Journal of feline Medicine and Surgery, 5(3): 183-189. 
Mishra A, Kumar S \& Pandey AK (2013). Scientific validation of the medicinal efficacy of Tinospora cordifolia. The Scientific World Journal, doi.10.1155/2013/292934

Moffett RO (1993). Sesotho plant and animal names and plants used by the Basotho. https://africansunmedia.snapplify.com/pub lisher/? $\mathrm{p}=\mathrm{SUN}+\mathrm{PRESS} \& \mathrm{t}=$. from https://africansunmedia.snapplify.com/pro duct/9781920383206, retrieved 12-052017.

Mohotti S, Rajendran S, Muhammad T, Strömstedt AA, Adhikari A, Burman R, De-Sliva ED, Goransson U, Hettiarachchi CM \& Gunasekera S (2020). Screening for bioactive secondary metabolites in Sri Lankan medicinal plants by micro fractionation and targeted isolation of antimicrobial flavonoids from Derris scandens. Journal of Ethnopharmacology, doi.10.1016/j.jep.2019.112158.

Nagata T, Ito S, Itoga K, Kanazawa H \& Masaki H (2015). The mechanism of melanocytesspecific cytotoxicity induced by phenol compounds having a prooxidant effect, relating to the appearance of leukoderma, BioMed Research International, doi.10.1155/2015/479798.

Nelson RW (2000). Oral medication for treating diabetes mellitus in dogs and cat. Journal of Small Animal Practice, 41(11): 486-490.

Ogundajo AL, Adeniran LA \& Ashafa AO (2018). Medicinal properties of Ocotea bullata stem bark extracts: Phytochemical constituents, antioxidant and anti-inflammatory activity, cytotoxicity and inhibition of carbohydratemetabolizing enzymes. Journal of Integrative Medicine, 16(2): 132-140.

Ohlund M, Fall T \& Strom H (2015). Incidence of diabetes mellitus in insured Swedish cats in relation to age, breed, and sex. Journal of Veterinary Internal Medicine, 29(5): 1342 1347.

Oku T, Tanabe K, Ogawa S, Sadamori N \& Nakamura $S$ (2011). Similarity of hydrolyzing activity of human and rat small intestinal disaccharidases. Clinical and Experimental Gastroenterology, doi.10.2147/CEG.S19961.

Olaokun OO, Mcgaw LJ, Rensburg IJ, Eloff JN \& Naidoo V (2016). Antidiabetic activity of the ethyl acetate fraction of Ficus lutea (Moraceae) leaf extract: Comparison of an in vitro assay with an in vivo obese mouse model. BMC Complementary and Alternative Medicine, 16(1): 1-12.

Phukhatmuen $\mathrm{P}$, Raksat $\mathrm{A}$, Laphookhieo $\mathrm{S}$ \& Charoensup R (2020). Heliyon Bioassayguided isolation and identification of antidiabetic compounds from Garcinia cowa leaf extract. Heliyon, doi.10.1016/j.heliyon.2020.e03625.

Re R, Pellegrini N, Proteggente A, Pannala A, Yang M \& Rice-Evans C (1999). Antioxidant activity applying an improved abts radical cation decolorization assay. Free Radical Biology and Medicine, 26(9): 1231-1237.

Reich E \& Schibli A (2007). High-performance thinlayer chromatography for the analysis of medicinal plants. Thieme. http://agris.fao.org/agrissearch/search.do?recordID=US2013001155 73, retrieved 20-08-2019.

Rengarajan S, Melanathuru V \& Govindasamy C (2020). Antioxidant activity of flavonoid compounds isolated from the petals of Hibiscus rosa sinensis. Journal of King Saud University of Science, 32(3): 2236-2242.

Rice-Evans CA, Miller NJ \& Paganga G (1996). Structure antioxidant activity relationships of flavonoids and phenolic acids. Free Radical Biology and Medicine, 20(7): 933956.

Sabiu S, O'Neill FH \& Ashafa AOT (2016). Kinetics of $\alpha$-amylase and $\alpha$-glucosidase inhibitory potential of Zea mays Linnaeus (Poaceae), Stigma maydis aqueous extract: An in vitro assessment. Journal of Ethnopharmacology, doi.10.1016/j.jep.2016.02.024.

Saeedi P, Petersohn I, Salpea P, Malanda B, Karuranga S, Unwin N, Stephen C, Leonor G, Ayesha A, Motala JE, Shaw D \& Bright R (2019). Global and regional diabetes prevalence estimates for 2019 and projections for 2030 and 2045: Results from the International Diabetes Federation Diabetes Atlas, nineth edition. Diabetes Research and Clinical Practice, doi.10.1016/i.diabres.2019.107843.

Shashank K \& Abhay K (2013). Chemistry and biological activities of flavonoids: An Overview. The Scientific World Journal, 4(2): 32-48.

Tadera K, Minami Y, Takamatsu K \& Matsuoka T (2006). Inhibition of alpha-glucosidase and alpha-amylase by flavonoids. Journal of Nutritional Science and Vitaminology, 52(2): 149-153. 
Tangvarasittichai S (2015). Oxidative stress, insulin resistance, dyslipidemia and type 2 diabetes mellitus. World Journal of Diabetes, 6(3): 456-480.

Teffo LS, Aderogba MA \& Eloff JN (2010). Antibacterial and antioxidant activities of four kaempferol methyl ethers isolated from Dodonaea viscosa Jacq. var. angustifolia leaf extracts. South African Journal of Botany, 76(1): 25-29.

Thomas V (2010). Phenylpropanoid biosynthesis. Molecular Plant, 3(1): 2-20.

Van-Acker SABE, Van-Den BD, Tromp MNJL, Griffioen DH, Van-Bennekom WP, Van-Der Vijgh WJF
\& Bast A (1996). Structural aspects of antioxidant activity of flavonoids. Free Radical Biology and Medicine, 20(3): 331342.

Wang T, Li Q \& Bi K (2018). Bioactive flavonoids in medicinal plants: Structure, activity and biological fate. Asian Journal of Pharmaceutical Sciences, 13(1): 12-23.

Bibi Z, Ayaz Z, Alwahibi MS, Khan S, Rizwana H, Soliman DW, Alawaad A \& Abbasi AM (2020). In-silico elucidation of Moringa oleifera phytochemicals against diabetes mellitus. Saudi Journal of Biological Sciences, doi.10.1016/j.sjbs.2020.04.002. 